\title{
FOSTERING UNDERGRADUATE STUDENTS' DIGITAL SKILLS IN EFL CLASS
}

\author{
ViviAulia \\ English Department, STKIP PGRI Banjarmasin, Indonesia \\ E-mail : viviauliavasa@yahoo.com
}

Submit: 24-11-2018 Review: 06-03-2019 Accepted: 21-03-2019

DOI: https://doi.org/10.22202/tus.2019.v5i1.2978

\begin{abstract}
This research aims at knowing what kinds of efforts have been carried out by EFL teachers to foster undergraduate students in some universities in Banjarmasin. Besides that, this research also wants to know the advantages, the obstacles, and the challenges faced by EFL teachers in Banjarmasin fostering undergraduate students' digital skills. This research takes place toward 15 EFL teachers in some universities in Banjarmasin who are selected as the participants to deliver information through questionnaire and interview. The questionnaire item consists of six elements of digital skills and its practice that are expected to be employed by EFL teachers in their classes while interview guide gains the additional information further on clarifying the advantages, the obstacles, and the challenges they face on fostering students' digital skills. The result of questionnaire shows that during a semester, the frequency of exploring digital-based learning is $75 \%$ from the whole meeting course duration at the average for all the EFL teachers under this research. Furthermore, the result of interview shows that fostering students' digital skills are not always successful in particular situation due to significant factors. The implementation of digital learning activities relies much on the availability of internet connection, the quality of internet network, the cost, and the degree of students' familiarity with the range of digital tools. These become the essential things to consider. This research concludes that fostering student' digital skills in EFL class needs optimal preparation, sufficient facilities available, and teaching plan from the teacher to get maximal learning outcomes.
\end{abstract}

Keywords: digital skill, EFL class, undergraduate students

\section{INTRODUCTION}

The development of technology encourages all elements of people knowing the world faster and easier. As far as with the development of technology in $21^{\text {st }}$ century, EFL learning should be set with the needs of worldwide change. In the past, traditional ways of teaching EFL dominantly use The Direct Method, The Audio-Lingual Method, The Grammar-Translation Method, The Silent Way, Suggestopedia, and so on leading to focus on creating beginner EFL learners' frameworks in understanding the concept of EFL learning (Grounds et al, 2014, 
p.10-33). The next time after the era of traditional ways, the field of EFL has changed dynamically and continually. The new idea of thinking how to teach EFL following the worldwide dynamic change has been proposed. In this process, less effective approaches and method are modified and replaced by those that seem to work better (Grounds et al., 2014, p.10).

Moving from traditional ways, the existence of these new approaches and methods have expanded and other related issues of updating the effective way of implementing EFL learning sound rapidly. Nevertheless, there is no best approach or method that can be said to be the effective way of learning. There is no single method stands alone. Each of EFL learning method supports the others method based on students' needs. New theories, information, and research are employed to see the effectiveness of each approach in past and present following the possible factors and particular situation.

In present situation, the new and the modern EFL learning methods are adapted with the worldwide change in which all education aspects have been influenced by the advancement of human resources. The increasing of qualified human resources highly depends on the mastery of knowledge and technology. The advancement of knowledge and technology present the innovation in the area of education and critical thinking skill. EFL field have developed with the issues and theories that require the learners to work with innovation. One of the EFL practices to involve with innovation is working with digital matters.

Modernization takes everything in all human life aspects. The digital world shows that the worldwide change requires us to have digital skill and competence. These skill and competence will contribute to people getting any information, to communicate, and to interact among people around the world easier and faster. This is because digital skill involves the capability to work altogether with the range of digital tools that are expected to facilitate many things in all human aspect. As stated by Saubari \& Baharuddin (2016, p.57), digital skill is not only talking about gaining the information, but also the knowledge using digital tools. Having digital skill will lead somebody to become a part of literacy 
process. These include the ability to find, to evaluate, to organize, to create, to interact, and to communicate using such digital tools as well.

Digital skill, knowledge, and practice are increasingly important in enabling learners to understand and to interact with digital world effectively and safely. Basic digital skill is needed to operate digital devices used for learning, such as: turning the computer or laptop on and off, operating the computer or laptop program, and working on it. These skills also include knowing how to create, to save, and to edit computer or laptop applications. These applications may include operating internet browsers for searching and finding information. Of course, the purpose of operating these internet browsers is a part of searching learning resources and updating the knowledge in a digital environment. The effective activities are ones that teach basic digital skill alongside language instruction and integrate it into the overall discussed topic in learning. Therefore, having digital skill makes a lifelong commitment to learn more feasible and attractive (Kukulska-Hulme et al, 2017, p.218).

In the area of EFL learning, digital tools have many advantages for those who utilize it properly and effectively. According to Ghavifekr \& Rosdy (2015, p.177), utilizing digital tools will be more interactive and engaging for students in EFL learning. Besides that, it can provide more options and nuances for some aspects as well as they are easily accessible from a variety of available devices, such as: smartphones, tablets, iPads, etc, to produce comprehensive teaching and learning environment. They offer ease and attractive things of doing all learning activities for students. Comparing to the traditional way of learning, digital tools are considered to save much time for those who utilize it effectively and wisely for learning needs.

Having digital skill provides possible variety of EFL activities for the teacher leading to the creation of a learning environment where technology helps boosting students' performances. Boonyopakorn (2016, p.200) emphasizes that the use of digital tools containing technology element into English practice has a lot benefits for EFL learners to promote English communication among them. Not only they will have digital competence that supports them in their study and 
society, but also they will have good attitudes towards using technology tools in language learning. Moreover, they also learn more about other countries like ASEAN countries where they will be able to communicate with Asians in English for further interaction in ASEAN Community effectively. The good point that the EFL learners has for these issues is they get learning experience by using digital tools to interact with people around the world in English that, in the future, will create them to have digital competence and skill.

Adapting from Laar et al (2017, p.583) and Benali et al (2018, p.100-108), there are six areas of digital skill and practice that can be integrated into the class promoting and fostering students' digital skills. Each of them are summarized and presented in Table 1 as follows:

Table 1.The Areas of Digital Skill and Practice

\begin{tabular}{|c|c|c|}
\hline No & $\begin{array}{l}\text { Areas of Digital } \\
\text { Skill and } \\
\text { Practice } \\
\end{array}$ & Example of Activities \\
\hline \multirow[t]{4}{*}{1} & \multirow{4}{*}{$\begin{array}{l}\text { ICT or Computer } \\
\text { Skill }\end{array}$} & $\begin{array}{l}\text { Using digital devices for everyday learning. Examples: } \\
\text { - Printing the learning material, assignment, document, etc. } \\
\text { - Using email, creating and working with documents, spreadsheet, PDF, } \\
\text { etc. } \\
\text { - Copying file, emailing a file, presenting using LCD projector, USB pen } \\
\text { drive, etc }\end{array}$ \\
\hline & & $\begin{array}{l}\text { Evaluating and selecting a device appropriate for learning use. Example: } \\
\text { choosing laptop, tablet, iPad, smartphone, and so on }\end{array}$ \\
\hline & & $\begin{array}{l}\text { Confidence in selecting, learning, and evaluating new software, tools, } \\
\text { website, etc. Example: using a Cloud service, such as Google Drive and } \\
\text { Dropbox to safely share documents between computers, devices, and people }\end{array}$ \\
\hline & & $\begin{array}{l}\text { Awareness of new development through media, social network and ability to } \\
\text { evaluate and to compare against current practice. Examples: } \\
\text { - Choosing among Facebook, WhatsApp, Instagram, LinkedIn, and other } \\
\text { social networks as the platform of learnin }\end{array}$ \\
\hline \multirow[t]{2}{*}{2} & \multirow[t]{2}{*}{ Information Skill } & $\begin{array}{l}\text { Finding content. Example: be aware and know when to use different } \\
\text { sources, for instance: using Google Scholar, Research Gate, Academia Edu, } \\
\text { online dictionary, library sources and subject database, etc. }\end{array}$ \\
\hline & & $\begin{array}{l}\text { Organizing and sharing resources. Example: using specialist software like } \\
\text { Mendeley, Endnote, etc }\end{array}$ \\
\hline \multirow{4}{*}{3} & \multirow{4}{*}{ Media Skill } & $\begin{array}{l}\text { Having awareness, experience, and understanding of a range of digital } \\
\text { media and its audience. Examples: } \\
\text { - Using blog, email, PDF, Youtube, Facebook, etc. } \\
\text { - Choosing appropriate language and content. }\end{array}$ \\
\hline & & $\begin{array}{l}\text { Creating media resources. Examples: } \\
\text { - Capturing with photo, video, and audio using digital camera, tablets, etc. } \\
\text { - Using text, video, and audio editing software like Adobe Photoshop } \\
\text { (image) and Audacity (audio) }\end{array}$ \\
\hline & & $\begin{array}{l}\text { Having awareness of Intellectual Property Right (IPR) laws. Examples: } \\
\text { - Having knowledge of how IPR applies to the use of content } \\
\text { - Having knowledge of content license }\end{array}$ \\
\hline & & $\begin{array}{l}\text { Communication. Examples: } \\
\text { - Using email, online forums, chat rooms, social networks }\end{array}$ \\
\hline
\end{tabular}




\begin{tabular}{|c|c|c|}
\hline \multirow[t]{2}{*}{4} & \multirow{2}{*}{$\begin{array}{l}\text { Communication } \\
\text { and } \\
\text { Collaboration }\end{array}$} & - Using Skype or other software for video calls \\
\hline & & $\begin{array}{l}\text { Collaboration. Examples: } \\
\text { - Working simultaneously on document in online environment like Google } \\
\text { Docs } \\
\text { - Participating in online discussion }\end{array}$ \\
\hline 5 & Learning Skill & $\begin{array}{l}\text { Identifying the appropriate tools to support critical thinking, academic } \\
\text { writing, note taking, etc. Examples: } \\
\text { - Using blog to publish the writing tasks } \\
\text { - Using Google, Wikipedia, Yahoo, to search information to support critical } \\
\text { thinking }\end{array}$ \\
\hline 6 & Problem Solving & $\begin{array}{l}\text { Using ICT to understand a problem situation in combination with the active } \\
\text { use of knowledge to find solution to a problem. Examples: } \\
\text { - Using ICT to acquire knowledge about the problem } \\
\text { - Using ICT to apply knowledge about the problem to find a solution. }\end{array}$ \\
\hline
\end{tabular}

Adapted from: Laar et al (2017, p.583) and Benali et al (2018, p.100-108)

Based on criteria presented in Table 1, digital skill consists of four main embedded issues in EFL learning that should be learned by students as a necessity to be literate learners. They are: using basic digital skill for supporting EFL learning, creating and communicating information in EFL learning, finding and evaluating information in EFL learning, and solving problems related to EFL learning in technology environment. Digital skill and EFL learning are frequently associated due to the consideration that higher education in Indonesia is required to prepare its graduates to be more competitive in the current fourth industrial revolution. Nasir (2018, p.16) states that one of disruptive innovation in higher education as following and participating in the fourth industrial revolution is the implementation of digital based-learning.

Dealing with the importance of discussing and investigating the use of digital tools in EFL learning, some related researches have been conducted by other researchers. Solano et al (2017, p.77-86) conducted a research about exploring the use of digital tools in EFL teaching in the south region of Ecuador. This study shows that Youtube-based videos, Power Point, and Prezi presentations are the most common digital tools used by the EFL teacher in Ecuador. These results are collaborated with the teachers' opinions that Youtube videos are the most popular tools used during the instructional activities because the students considered them very motivating for EFL learning.

Another similar research is conducted by Durriyah \& Zuhdi (2018, p.5360 ). They conducted a study on the kinds of digital technologies in which the 
students-teacher select to integrate into their teaching plan. The result of the study shows that they utilize four kinds of digital platform to be integrated in EFL learning. They are: facebook close group, web-blogs, skype application, and whatsapp application.

Considering that there are many varieties of digital tools have been utilized for promoting and supporting students to have digital skill, this research tries to investigate the effort of EFL teachers who teach undergraduate students of English major in Banjarmasin, South Kalimantan, to foster students' digital skills. The purpose of this research is to know what kinds of efforts have been carried out by EFL teachers to foster undergraduate students in some universities in Banjarmasin. Besides that, this research also wants to know the advantages, the obstacles, and the challenges that are faced by them fostering students' digital skills in EFL class.

Furthermore, it is expected that this research gives significant contribution in the area of EFL teaching both theoretically and practically. Theoretically, this research will give description on the specific elements of digital skills should be mastered by EFL teacher and students to meet digital era in the fourth industrial revolution. Further, practically, this research guides the EFL teacher to train their students with real practice of digital skills area into EFL learning regarding the learning environment and the students' needs.

\section{METHODS}

This research employed descriptive design with quantitative and qualitative approaches aimed at describing and discovering the fact and the behavior about the effort of $15 \mathrm{EFL}$ teachers in Banjarmasin fostering undergraduate students' digital skills. It used quantitative approach since this research tried to discover the frequency of teachers think, act, and feel the specific way on the digital skills practices have been carried out by them which was investigated using questionnaire. Furthermore, this research also used qualitative approach in which the data were also gained by open-ended questions which 
required more thought and more than a simple one-word answer through interview section to support the result of the questionnaire.

This research took place toward 15 EFL teachers in Banjarmasin where they worked in the universities teaching English major. They were taken as participants based on consideration that they were active teachers in teaching English majors and have the relevant academic background in the area of teaching EFL for undergraduate level. All the participants of this research were selected due to their experiences in teaching EFL utilizing digital tools in their classes.

The instruments of collecting the data of this research were questionnaire and interview guide. The questionnaire was distributed to the participants in collecting the data on EFL learning activities employed by them utilizing digital tools. The items of questionnaire were developed based on the criteria of digital skills in Table 1. The elements of digital skills and practices should be completed with the frequency of EFL teacher utilizing digital tools in their classes during a semester.

There were 16 items of statement provided in the distributed questionnaire. The option of the response consisted of Likert time scale presenting the frequency of EFL teacher exploring digital-based learning. They were always $(100 \%$ of the teachers used the digital tools in their classes during the whole meeting duration in a semester), frequently (80\%), often (70\%), sometimes (50\%), seldom (10\%) and never $(0 \%)$. Each of time scale was given score 6 maximally and 1 minimally. The Likert time scale was used based on consideration that it measured the extent to which the teachers apply the practices of digital-based learning to the students with provided statements in the questionnaire.

In order to make sure that the questionnaire was reliable enough to be applied for gathering the data, a pilot study of eight EFL teachers from English Department of STKIP PGRI Banjarmasin was carried out. These EFL teachers were asked to complete the questionnaire twice with the same provided questions. The first period of completing the questionnaire could be accomplished in two days. Four days later, they were asked to complete it again for the second period. After that, the scores of pilot study were calculated and the reliability test was 
administered to get the Cronbach's Alpha reliability coefficients. The calculated reliability coefficient was 0.73 indicating that the questionnaire was reliable enough to be used for gathering the data of this research.

Besides measuring the reliability, the researcher also measured the validity of the questionnaire. A set of questionnaire was sent to an EFL teacher of Lambung Mangkurat University of Banjarmasin who was considered as an active researcher in the area of education. He reviewed the content of questionnaire and gave recommendation to modify some parts of provided questions to get specific result. The recommendation was highly considered and the questionnaire was modified twice before getting its final draft. After finishing the questionnaire draft, it was distributed to the 15 EFL teachers under this research to gain the data. Then, the data from questionnaire were tabulated in the table to see the percentage of answer given by the teachers.

In addition, the interview guide was used to collect additional information from the participants relating to their perspectives on the advantages, the obstacles, and the challenges in using digital tools. The interview guide was constructed based on the elements of digital skills in Table 1. The ten items of open-ended questions were employed in the interview guide to ensure that each of interviewee stated a full, meaningful answer by using their knowledge and feeling.

Furthermore, interview section also tried to gain specific information that has not been covered in the questionnaire as well as got additional ideas behind the given response in questionnaire by all the participants. The result of interview section was tabulated in form of table. It presented the most frequent response from all the participants. After that, the final conclusion was drawn based on the analysis of the data.

\section{FINDING AND DISCUSSION}

The results of this research present the findings derived from the investigation. Then, the findings are discussed with supporting relevant literature. They are presented in the following part. 


\section{Findings of the Questionnaire}

The result of questionnaire was derived from the frequency of EFL teachers in Banjarmasin exploring digital-based learning to foster students' digital skills during the whole meeting duration in a semester are presented in the Table 2 as follows:

Table 2. The Frequency of Exploring Digital-Based Instruction by EFL Teachers

\begin{tabular}{|c|c|c|c|c|c|c|c|}
\hline \multirow{3}{*}{ No } & \multirow{2}{*}{$\begin{array}{l}\text { Questionnaire Item in } \\
\text { the Areas of Digital } \\
\text { Skill and Practice }\end{array}$} & \multicolumn{6}{|c|}{$\begin{array}{c}\text { The Number of EFL Teachers Exploring } \\
\text { Digital-Based Learning }\end{array}$} \\
\hline & & Always & Frequently & Often & Sometimes & Seldom & Never \\
\hline & \multicolumn{7}{|c|}{ I. ICT or Computer Skill } \\
\hline 1 & $\begin{array}{l}\text { Together with the } \\
\text { students, I utilize digital } \\
\text { device for everyday } \\
\text { learning }\end{array}$ & $7 \%$ & $27 \%$ & $53 \%$ & $13 \%$ & - & - \\
\hline 2 & $\begin{array}{l}\text { I train the students in } \\
\text { class to evaluate and to } \\
\text { select a device } \\
\text { appropriate for learning } \\
\text { use, such as: choosing } \\
\text { tablet, laptop, iPad, } \\
\text { smartphone, etc }\end{array}$ & $13 \%$ & $47 \%$ & $40 \%$ & - & - & - \\
\hline 3 & $\begin{array}{l}\text { I encourage and } \\
\text { stimulate the students in } \\
\text { class to be confidence } \\
\text { in selecting, learning, } \\
\text { and evaluating new } \\
\text { software, tools, website, } \\
\text { etc, used for learning }\end{array}$ & - & $53 \%$ & $47 \%$ & - & - & - \\
\hline 4 & $\begin{array}{l}\text { I encourage the students } \\
\text { in class to have } \\
\text { awareness of new } \\
\text { development through } \\
\text { media and social } \\
\text { network for learning }\end{array}$ & - & $47 \%$ & $33 \%$ & $20 \%$ & - & - \\
\hline 5 & $\begin{array}{l}\text { I train the students in } \\
\text { class to } r \text { select } \\
\text { appropriate } r \\
\begin{array}{l}\text { network forial } \\
\text { activities }\end{array}\end{array}$ & - & $47 \%$ & $33 \%$ & $20 \%$ & - & - \\
\hline & Average & $10 \%$ & $44 \%$ & $41 \%$ & $18 \%$ & & \\
\hline \multicolumn{8}{|c|}{ II. Information Skill } \\
\hline 6 & $\begin{array}{l}\text { I train the students in } \\
\text { class on finding content } \\
\text { using different sources, } \\
\text { such as: using Google, } \\
\text { Yahoo, ResearchGate, } \\
\text { Academia Edu, online } \\
\text { dictionary, etc. }\end{array}$ & $100 \%$ & - & - & - & - & - \\
\hline 7 & $\begin{array}{l}\text { I train the students in } \\
\text { class to organize the } \\
\text { material using digital } \\
\text { software, such as: }\end{array}$ & - & - & $20 \%$ & $53 \%$ & $27 \%$ & - \\
\hline
\end{tabular}




\begin{tabular}{|c|c|c|c|c|c|c|c|}
\hline & $\begin{array}{l}\text { Mendeley, Grammarly, } \\
\text { etc. }\end{array}$ & & & & & & \\
\hline & Average & $100 \%$ & - & $20 \%$ & $53 \%$ & $27 \%$ & \\
\hline \multicolumn{8}{|c|}{ III. Media skill } \\
\hline 8 & $\begin{array}{l}\text { I train the students in } \\
\text { class to have awareness, } \\
\text { experience, and } \\
\text { understanding of a } \\
\text { range of digital media } \\
\text { and its audience }\end{array}$ & - & $13 \%$ & $80 \%$ & $7 \%$ & - & - \\
\hline \multirow[t]{2}{*}{9} & $\begin{array}{l}\text { I ask and invite the } \\
\text { students in class } \\
\text { creating }\end{array}$ & & & & & & \\
\hline & $\begin{array}{l}\text { resources, such as: } \\
\text { capturing photo, video, } \\
\text { audio, as well as using } \\
\text { text, video, and audio } \\
\text { editing software for } \\
\text { learning activities }\end{array}$ & - & $60 \%$ & $40 \%$ & - & - & - \\
\hline & Average & - & $36.5 \%$ & $60 \%$ & $7 \%$ & - & \\
\hline \multicolumn{8}{|c|}{ IV. Communication and Collaboration } \\
\hline 10 & $\begin{array}{l}\text { I utilize email, online } \\
\text { forums, chat rooms, and } \\
\text { social networks for } \\
\text { everyday } \\
\text { communication and } \\
\text { interaction in class }\end{array}$ & $33 \%$ & $67 \%$ & - & - & - & - \\
\hline 11 & $\begin{array}{l}\text { I utilize Skype or other } \\
\text { software for video calls } \\
\text { in everyday } \\
\text { communication and } \\
\text { interaction in class }\end{array}$ & - & - & - & - & - & $100 \%$ \\
\hline 12 & $\begin{array}{l}\text { I instruct the students in } \\
\text { class to participate in } \\
\text { online class discussion }\end{array}$ & - & $20 \%$ & $40 \%$ & $40 \%$ & - & - \\
\hline & Average & $33 \%$ & $43.5 \%$ & $40 \%$ & $40 \%$ & - & $100 \%$ \\
\hline \multicolumn{8}{|c|}{ V. Learning Skill } \\
\hline 13 & $\begin{array}{l}\text { Together with the } \\
\text { students, I utilize digital } \\
\text { tools to support critical } \\
\text { thinking, academic } \\
\text { writing, note taking, } \\
\text { etc. }\end{array}$ & - & $20 \%$ & $40 \%$ & $40 \%$ & - & - \\
\hline 14 & $\begin{array}{l}\text { I instruct the students in } \\
\text { class to use Google, } \\
\text { online journal, etc. to } \\
\text { search information } \\
\text { supporting critical } \\
\text { thinking }\end{array}$ & $33 \%$ & $47 \%$ & $20 \%$ & - & - & - \\
\hline & Average & $33 \%$ & $67 \%$ & $30 \%$ & $40 \%$ & - & - \\
\hline \multicolumn{8}{|c|}{ VI. Problem Solving } \\
\hline 15 & $\begin{array}{l}\text { I train the students in } \\
\text { class using ICT tools } \\
\text { acquiring knowledge } \\
\text { about the learning } \\
\text { problem }\end{array}$ & - & - & $73 \%$ & $27 \%$ & - & - \\
\hline 16 & $\begin{array}{l}\text { I train the students in } \\
\text { class using ICT tools } \\
\text { applying knowledge } \\
\text { about the learning } \\
\text { problem to find }\end{array}$ & - & - & $27 \%$ & $73 \%$ & - & - \\
\hline
\end{tabular}




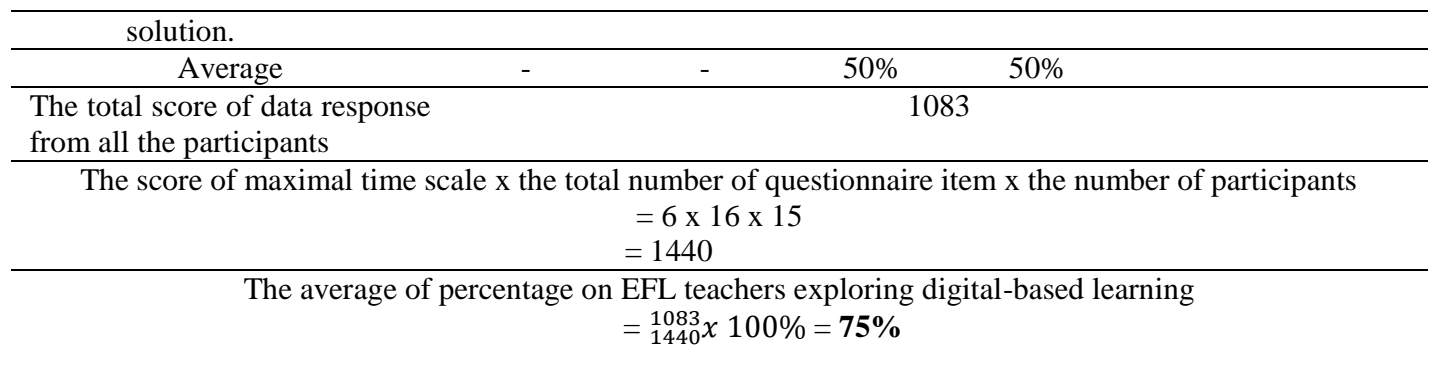

(Source: Questionnaire Analysis, 2018)

Based on the result of questionnaire in Table 2, it can be concluded that the average frequency of EFL teacher in Banjarmasin to explore the digital-based learning fostering undergraduate students' digital skills during a semester was $75 \%$ of the whole meeting duration in their classes. In other words, at the average, they often utilize the digital tools in their classes during a semester. This indicated that the effort of EFL teachers in Banjarmasin to foster undergraduate students' digital skills was good enough.

\section{Findings of Interview with the EFL Teachers in Banjarmasin}

The result of interview was derived from the further explanation and information given by $15 \mathrm{EFL}$ teachers in Banjarmasin under this research fostering undergraduate students' digital skills in their classes. These data presented the additional information that has not been covered in the questionnaire. The result of interview was presented in Table 3 as follows:

Table 3. The Result of Interview

\begin{tabular}{|c|c|c|c|}
\hline No & Questions & Response Given by EFL Teachers & Percentage \\
\hline \multirow[t]{3}{*}{1} & \multirow{3}{*}{$\begin{array}{l}\text { What are the kinds of EFL } \\
\text { learning activities you teach } \\
\text { most for utilizing the digital } \\
\text { tools? }\end{array}$} & $\begin{array}{l}\text { Reading (basic reading, advance reading, } \\
\text { extensive reading, and so on) }\end{array}$ & $40 \%$ \\
\hline & & $\begin{array}{l}\text { Writing (paragraph writing, academic } \\
\text { writing, essay writing, and so on) }\end{array}$ & $40 \%$ \\
\hline & & Speaking, listening, and others & $7 \%$ \\
\hline \multirow[t]{3}{*}{2} & \multirow{3}{*}{$\begin{array}{l}\text { What are the kinds of activities } \\
\text { you have carried out to foster } \\
\text { students' ICT or computer } \\
\text { skill? }\end{array}$} & $\begin{array}{l}\text { Printing the learning material, } \\
\text { assignment, document, etc }\end{array}$ & $100 \%$ \\
\hline & & $\begin{array}{l}\text { Working with email, document, } \\
\text { spreadsheets, PDF, etc. It includes } \\
\text { copying file, emailing file, presenting } \\
\text { using LCD projector, USB pen drive, and } \\
\text { so on }\end{array}$ & $100 \%$ \\
\hline & & $\begin{array}{l}\text { Choosing among social networks as the } \\
\text { platform of learning, such as: Facebook, } \\
\text { WhatsApp, Youtube, LinkedIn, Edmodo, }\end{array}$ & $73 \%$ \\
\hline
\end{tabular}




\begin{tabular}{|c|c|c|c|}
\hline & & Google Class, and so on & \\
\hline \multirow[t]{2}{*}{3} & \multirow[t]{2}{*}{$\begin{array}{l}\text { What are the kinds of activities } \\
\text { you have carried out to foster } \\
\text { students' information skill? }\end{array}$} & $\begin{array}{l}\text { Finding learning material by using } \\
\text { Google, Yahoo, Google Scholar, } \\
\text { ResearchGate, Academia Edu, online } \\
\text { dictionary, and so on }\end{array}$ & $100 \%$ \\
\hline & & $\begin{array}{l}\text { Organizing the learning material using } \\
\text { online software like Mendeley, } \\
\text { Grammarly, and so on }\end{array}$ & $40 \%$ \\
\hline \multirow[b]{2}{*}{4} & \multirow{2}{*}{$\begin{array}{l}\text { What are the kinds of activities } \\
\text { you have carried out to foster } \\
\text { students' media skill? }\end{array}$} & $\begin{array}{l}\text { Using blog, email, PDF, Youtube, and so } \\
\text { on for learning needs }\end{array}$ & $87 \%$ \\
\hline & & $\begin{array}{l}\text { Creating photo, text, video, and audio as } \\
\text { well as using text, video, and audio } \\
\text { editing software like Adobe Photoshop, } \\
\text { and so on for learning needs }\end{array}$ & $67 \%$ \\
\hline \multirow[t]{2}{*}{5} & \multirow[t]{2}{*}{$\begin{array}{l}\text { What are the kinds of activities } \\
\text { you have carried out to foster } \\
\text { students' communication and } \\
\text { collaboration skills? }\end{array}$} & $\begin{array}{l}\text { Utilizing email, online forums through } \\
\text { WhatsApp, Line, and Telegram } \\
\text { applications, and so on for everyday } \\
\text { communication and interaction with the } \\
\text { students in class }\end{array}$ & $100 \%$ \\
\hline & & $\begin{array}{l}\text { Utilizing online class discussion through } \\
\text { Facebook Chat Group }\end{array}$ & $80 \%$ \\
\hline \multirow[b]{2}{*}{6} & \multirow{2}{*}{$\begin{array}{l}\text { What are the kinds of activities } \\
\text { you have carried out to foster } \\
\text { students' learning skills? }\end{array}$} & $\begin{array}{l}\text { Using blog to publish students' writing } \\
\text { assignment }\end{array}$ & $47 \%$ \\
\hline & & $\begin{array}{l}\text { Using Youtube and Instagram to publish } \\
\text { students' speaking and listening training } \\
\text { activities }\end{array}$ & $33 \%$ \\
\hline \multirow[t]{2}{*}{7} & \multirow[t]{2}{*}{$\begin{array}{l}\text { What are the kinds of activities } \\
\text { you have carried out to foster } \\
\text { students' skills in solving the } \\
\text { learning problem by utilizing } \\
\text { ICT? }\end{array}$} & $\begin{array}{l}\text { Using PDF books and article, } \\
\text { downloading online article journal, using } \\
\text { online and offline dictionary, to gain the } \\
\text { information on the issues of students' } \\
\text { learning problem }\end{array}$ & $100 \%$ \\
\hline & & $\begin{array}{l}\text { Using TransTool, iTranslate, Microsoft } \\
\text { Translator, Grammarly, and so on to help } \\
\text { students organizing their works }\end{array}$ & $73 \%$ \\
\hline \multirow[b]{2}{*}{8} & \multirow[b]{2}{*}{$\begin{array}{l}\text { What are the advantages of } \\
\text { utilizing digital tools as an } \\
\text { effort of fostering students' } \\
\text { digital skills? }\end{array}$} & Easier to work everyday and everywhere & $73 \%$ \\
\hline & & $\begin{array}{l}\text { Various references can be accessed easily } \\
\text { like article, magazine, journal, and so on } \\
\text { as alternative of learning, instead of } \\
\text { depending on printed book only }\end{array}$ & $100 \%$ \\
\hline 9 & $\begin{array}{l}\text { What are the obstacles of } \\
\text { utilizing digital tools as an } \\
\text { effort of fostering students' } \\
\text { digital skills? }\end{array}$ & $\begin{array}{l}\text { Since it needs the active participation } \\
\text { from all the students, sufficient package } \\
\text { of internet data should be available for } \\
\text { each of them. It needs much cost to have } \\
\text { sufficient package of internet data. }\end{array}$ & $100 \%$ \\
\hline \multirow[t]{2}{*}{10} & \multirow[t]{2}{*}{$\begin{array}{l}\text { What are the challenges of } \\
\text { fostering students having } \\
\text { digital skills? }\end{array}$} & $\begin{array}{l}\text { Not all students are familiar with many } \\
\text { ranges of digital tools. They often feel } \\
\text { anxious on the trouble occur working } \\
\text { with them }\end{array}$ & $60 \%$ \\
\hline & & $\begin{array}{l}\text { Less adequate of digital facilities in the } \\
\text { college }\end{array}$ & $40 \%$ \\
\hline
\end{tabular}

(Source: Interview Analysis, 2018)

Based on the result of interview in Table 3, it can be concluded that each item of interview guide has various trends on the teachers' responses. First, the digital tools were dominantly used by teacher to teach reading and writing skills (40\%). Second, $100 \%$ of EFL teachers under this research fostered students' ICT 
skill by training students printing the learning material as well as working with ICT tools. Next, 100\% of EFL teachers under this research fostered students' information skill by finding learning material from online search engine. Fourth, $87 \%$ of teachers used blog, email, and other digital platforms fostering students' media skill. Fifth, $100 \%$ of teachers utilized social media for everyday communication and collaboration among students. Next, $47 \%$ of teachers utilized blog to publish students' writing assignment fostering their learning skill. Seventh, all the teachers (100\%) used internet to find out such additional learning resources fostering students' skills in solving the learning problem. Eighth, 100\% of teachers stated that the positive thing of utilizing digital tools was training students to be creative finding out various learning references from the internet. Next, $100 \%$ of teachers agreed that utilizing internet has consequences on the high cost should be spent by students buying internet package data. The last result is $60 \%$ teachers agreed that not all students were familiar with many range of digital tools since they came from various background in which some of them did not learn using digital tools before entering university. This became the challenge of fostering undergraduate students' digital skills in which the teacher should consider in the future.

\section{Discussion}

Digital skill is one of required skills for those who want to compete for the $21^{\text {st }}$ century. Education supports the acquisition of the skills required to use technologies while technologies itself support the teaching and learning process. It is expected that the use of digital technologies in educational establishments encourage the better learning. Based on the findings of this research, EFL teachers in Banjarmasin have performed possible efforts to support the undergraduate students having digital skills.

The general result that encounter the possibility of EFL teachers in Banjarmasin fostering undergraduate students' digital skills are when they teach reading and writing courses. Based on the result of interview, the high percentage of them enjoy and feel comfortable when exploring digital-based learning in 
reading and writing courses, such as: asking them to read various text types from electronic books, creating mind mapping of the reading text by using offline application, making summary by utilizing graphic organizer application, publishing their writing tasks in blog, searching references through Google, Yahoo, and so on.

Among other English language skills and other EFL learning activities, reading and writing are considered as urgent language skills that students need in order to be successful in university. Umunnakwe \& Sello (2016, p.1342) emphasize that at the university level, the students study with huge amount of material in all their courses. As they are expected to read these materials, they also need to comprehend and to process the material by writing activities, such as: making notes, writing the tasks, making reports, doing the test and examination, writing email, and so on. Therefore, having sufficient reading and writing skills will contribute much on various disciplines and across curriculum.

In the context of exploring digital-based learning as the effort of EFL teachers to foster undergraduate students' digital skills, there are some findings from this research. The result of questionnaire shows that most of EFL teachers in Banjarmasin are frequently enough utilizing ICT tools (44\%) and using other digital tools to support students having learning skills (67\%). ICT or computer skill is the basic digital skill the students should master. ICT or computer skill which includes the ability of students operating computer or laptop as well as processing hardware and software tools are the main central roles supporting today's life. This is in line with the statement of Nwosu et al $(2018, p .582)$ that undergraduate students are the young generation who will work in the society. They are highly expected to acquire and to transfer the knowledge, skill, and attitude using information and communication technology through ICT matter.

In the context of utilizing digital tools to foster students' learning skills, most of EFL teachers in this research are familiar enough using some social platforms for learning needs. Publishing students' writing tasks in public blog, using Youtube channel and Instagram application to publish students' speaking and listening training activities are the examples of possible efforts that have been 
executed by them to train students' learning skills. Blog, Youtube, and Instagram, are some examples of the most widely used and easiest platform to operate by students for publishing any material and various learning activities. Not only these platforms provide students to publish their works, but also these can be used for creating photo, text, video, and audio to support their learning needs.

Furthermore, $100 \%$ of EFL teachers in Banjarmasin have carried out the most widely used activities for finding content, material, information, and learning sources by using search engine like Google, Yahoo, Mozilla Firefox, and so on. Moreover, they also train student searching additional material through Google Scholar or Research Gate as the research sites provide databases of published and shared research articles to enlarge students' knowledge. Due to the limitation of printed books available in the library for students to search and to get the information, the existence of search engine and research sites have become the solution for them to update information about the learning sources based on their needs. Accessible search engine and research sites provide million contents that enable students increasing their literacies and information skill. Nikolopoulou \& Gialamas (2011, p.30) mention that utilizing search engine and research site databases are the crucial part of the information search process for undergraduate students. Students' training is useful to include practical experiences on relevant searching activities, so as to be able to obtain and to evaluate information independently in the digital area.

In the area of communication and collaboration skills, social networks are already utilized by most of EFL teachers under this research to interact and to communicate each other. Email, online forum through WhatsApp, Line, and Telegram applications as well as Facebook Chat Group are some of social networks that all the people can interact each other efficiently in which if a person sends a message, the others can read, response, and give feedback on it so that the further discussion is possible to do beyond the classroom. Froment et al (2017, p.126-144) conduct a research on the use of social networks as a communication tool between teachers and students. The result of the research shows that in relation to the most used social networks by teachers and students as a 
communication tool, they emphasize Facebook and WhatsApp due to its popularity among the young population and for offering a great variety of interactive tools.

The essential result of this research also comes from the kinds of activities the EFL teachers in Banjarmasin have carried out to foster undergraduate students' skills in solving the learning problem using ICT. Most of students complain about the limited number of reference books available in the college library. Very few printed books available in the library can be used as reference sources. Addressing this problem, the teachers ask them actively to allocate time searching PDF books and online article to solve their problems. There is no reason for depending on printed book only since digital tools provide many things to solve their problems. Besides that, most students feel less confident on writing course so that they use such translation machine and grammar controller machine to help them organize their works. The teacher also always reminds them to control the work of translator and grammar controller machines so that the validity and accuracy of their works are accountable under the students themselves as the controllers.

Exploring digital-based learning is not always well run in EFL class. There are advantages of fostering students' digital skills, otherwise, in particular case and situation, there will be obstacles and the challenges both the teachers and the students have. As stated on the Table 3 that $100 \%$ of them reveal that digital world provides various references that can be accessed easily and efficiently from the internet. Since traditional way of learning depends much on printed document, the development of digital world also changes the way of students' learning around the world. Most of printed book have been transformed in forms of open access electronic books. All the internet users can access the book database provider easily every time and everywhere (Prasojo et al., 2017,p.47).

Furthermore, the advance of digital sources also changes the old paradigm that the textbook is the only one used for learning resources. Besides the book, teachers around the world also introduce students to read the articles from scientific journals that are used as primary sources in the academic matter. They 
introduce Research Gate, Google Scholar, ERIC, and so forth as some of sites providing published scientific article that can be read to enlarge students' scientific knowledge. Ayub et al (2014, p.238) emphasize that most libraries in universities and colleges have subscribed to online journal databases, online books, and other academic resources for their students' usage, instead of limitation of printed books. Hence, the higher education has obligation to contribute fostering and training students seeking relevant information and materials scientifically to complete their assignment or projects in today's digital era.

The other voices from EFL teachers in Banjarmasin are revealed in case of the obstacles of fostering undergraduate students' digital skills. Utilizing the digital tools in learning activities is not always successful. Since the digital activity relies on the availability of internet network, both the teacher and the students should have sufficient package of internet data. In fact, not all students have much internet data package due to its cost. As a result, the teacher suggests them to use the available Wifi internet in the college to help them access the internet network. However, the high duration of wifi internet which is almost used by all people in the college causes unstable and trouble on its network connection. Addressing these problems, digital-based learning cannot be explored maximally in particular activities. The expensive cost of providing internet data is also considered by all the teachers as none of them (100\%) utilize Skype for communication and collaboration in EFL class since operating this application consumes more data. This is in line with the research conducted by Prasojo et al (2017, p.47) that internet connection and its cost become the two big of problems the digital users mostly have utilize the digital matter.

The last finding that is important to discuss is about the challenge of fostering undergraduate students' digital skills. Beyond the advantages as well as the obstacle occurring in digital-based learning; there are challenges to think further in the future. Since we live in digital era offering everything goes easily, however, this digitalization is not always reflected successfully to students. Not all students are comfortable working with technology. Not all of them have 
knowledge and familiar with many ranges of digital tools. Sometimes, they feel anxious and frustrated on the digital trouble and do not have experience on how to repair it. Byungura et al $(2018$, p.43) imply that in order to increase their familiarity with technology, the students have to be introduced to available educational technologies at the early starting of their university course activities. Indeed, it also becomes the future challenges for many universities, particularly in Banjarmasin to develop and to provide adequate digital learning facilities supporting the effective of learning

Finally, the result of this research emphasizes some points to consider. Exploring digital-based learning to foster undergraduate students' digital skills in EFL is complicated. Digital skill requires students to work independently with technology that may be resulted on less of teacher attention. Addressing this point, a pedagogical teaching plan is necessary to ensure the optimal use of technologies in a learning environment.

\section{CONCLUSION}

This research has found out that EFL teachers in some universities in Banjarmasin have carried out digital-based learning by utilizing possible digital tools for learning needs. At the average, the EFL teachers in Banjarmasin under this research allocate $75 \%$ of the whole meeting duration in their classes for a semester to explore digital-based learning. Fostering students' digital skills are implemented on six elements of digital skill and its practice with various results. They are ICT or computer skill, information skill, media skill, communication and collaboration, learning skill, and problem solving skill.

Considering that these efforts are not easy to do and its optimal result depends on many significant factors, there are advantages, obstacles, and challenge both the teachers and the students have. Since the digital tools offer ease and effectiveness on all aspects of human life, they also sometimes cause feeling uncomfortable due to the high cost that should be allocated. Finally, this research suggests to the EFL teachers to have optimal preparation, sufficient facilities, and constructive teaching plan to carry out digital-based learning. 


\section{REFERENCES}

Ayub, A. F. ., Hamzari, W. H. ., \& Nawawi, M. . (2014). Use Of Internet For Academic Purposes Among Students In Malaysian Institutions Of Higher Education. The Turkish Online Journal of Educational Technology (TOJET), 13(1), 232-241.

Benali, M., Kaddouri, M., \& Azzimani, T. (2018). Digital competence of Moroccan teachers of English. International Journal of Education and Development Using Information and Communication Technology (IJEDICT), 14(2), 99-120.

Boonyopakorn, J. (2016). Technology Enhanced Language Learning on English Communication for EFL Learners. In Proceeding of the 10th International Multi-Conference on Society, Cybernetics, and Information (IMSCI) (pp. 200-205).

Byungura, J. C., Hansson, H., Muparasi, M., \& Ruhinda, B. (2018). Familiarity with Technology among First-Year Students in Rwandan Tertiary Education. The Electronic Journal of E-Learning, 16(1), 30-45.

Durriyah, T. L., \& Zuhdi, M. (2018). Digital Literacy With EFL Student Teachers : Exploring Indonesian Student Teachers' Initial Perception About Integrating Digital Technologies Into a Teaching Unit. International Journal of Education and Literacy Studies, 6(3), 53-60.

Froment, F., González, A. J. ., \& Bohorquez, M. R. (2017). The Use of Social Networks as a Communication Tool between Teachers and Students: A Literature Review. The Turkish Online Journal of Educational Technology (TOJET), 16(4), 126-144.

Ghavifekr, S., \& W.A.W, R. (2015). Teaching and Learning with Technology: Effectiveness of ICT Integration in Schools Teaching and Learning with Technology: Effectiveness of ICT Integration in Schools. International Journal of Research in Education and Science (IJRES), 1(2), 175-191.

Grounds, P., Guerrero, S., Lethaby, C., Moore, C., \& Werff, J. V. . (2014). Primary Methodology Handbook Practical Ideas for ELT with DVD. In S. Guerrero (Ed.), Primary Methodology Handbook Practical Ideas for ELT with DVD (pp. 1-40). Del. Benito Juarez: Richmond Publishing.

Kukulska-Hulme, A., Lee, H., \& Norris, L. (2017). Mobile Learning Revolution : Implications for Language. https://doi.org/10.1002/9781118914069

Laar, E. Van, Deursen, A. J. A. M. Van, Dijk, J. A. G. M. Van, \& Haan, J. De. 
(2017). The relation between 21st-century skills and digital skills: A systematic literature review Computers in Human Behavior The relation between 21st-century skills and digital skills : A systematic literature review. Computers in Human Behavior, 72(October), 577-588. https://doi.org/10.1016/j.chb.2017.03.010

Nasir, M. (2018). Policy for Curriculum and Competencies in the 4th Industrial Revolution. Retrieved from https://www.theewf.org/uploads/pdf/D1-16.00HE-Dr-Mohamad-Nasir.pdf

Nikolopoulou, K., \& Gialamas, V. (2011). Undergraduate students ' information search practices. Themes in Science and Technology Education, 4(1), 21-32.

Nwosu, J. C., John, H. C., Izang, A. A., \& Akorede, O. J. (2018). Assessment of information and communication technology ( ICT ) competence and literacy skills among undergraduates as a determinant factor of academic achievement. Educational Research and Reviews, 13(15), 582-589. https://doi.org/10.5897/ERR2018.3539

Prasojo, L. D., Habibi, A., Mukminin, A., Muhaimin, Taridi, M., Ikhsan, \& Saudagar, F. (2017). Managing Digital Learning Environments: Student Teachers ' Perception on the Social Networking Services Use in Writing Courses in Teacher Education. The Turkish Online Journal of Educational Technology (TOJET), 16(4), 42-55.

Saubari, N., \& Baharuddin, M. F. (2016). Digital Literacy Awareness among Students. Research Hub, 2(October), 57-63.

Solano, L., Cabrera, P., Ulehlova, E., \& Espinoza, V. (2017). EXPLORING THE USE OF EDUCATIONAL TECHNOLOGY IN EFL TEACHING : A CASE STUDY OF PRIMARY EDUCATION IN THE SOUTH REGION OF ECUADOR. Teaching English with Technology, 17(2), 77-86.

Umunnakwe, N., \& Sello, Q. (2016). Effective Utilization of ICT in English Language Learning - The Case of University of Botswana Undergraduates. Universal Journal of Educational Research, 4(6), 1340-1350. https://doi.org/10.13189/ujer.2016.040611

\section{BIOGRAPHY}

Vivi Aulia obtained her master degree in English Education from State University of Malang (2011). She is now an English lecturer at the English Department, STKIP PGRI Banjarmasin, Kalimantan Selatan, Indonesia. She is interested conducting research focusing in the area of EFL teaching and education in general. 
